\title{
Perception and Intention to Use E-learning from Students' Point of View- An Evidence from Malaysia Local University
}

\author{
Salina Mad ${ }^{1 *}$, Nor Alwani Omar², Ezzah Suraya Sarudin ${ }^{3}$, Nurul Hidayah Aziz ${ }^{4}$ \\ ${ }^{1}$ Faculty of Accountancy \\ ${ }^{2,3}$ Faculty of Computer and Mathematical Sciences \\ ${ }^{4}$ Academy of Contemporary Islamic Studies \\ Universiti Teknologi MARA Perak Branch, Tapah Campus, 35400 Tapah Road, Perak, Malaysia \\ Corresponding author: *salina2439@uitm.edu.my
}

Received Date: 2 October 2020

Accepted Date: 9 October 2020

\begin{abstract}
Education landscape has changed dramatically due to Covid19 pandemic as in many country, conventional or face-to-face teaching and learning is no longer an option to avoid the spread of a virus. E-learning become one of the best alternative to ensure education process could continue because experts believe world could only recover from this crisis in another two years. This paper will delve into students' perspective about e-learning and their willingness to use e-learning. Technology Acceptance Model (TAM) was used to outlined this study. Majority of the student have an idea about what is e-learning. They also agree that e-learning able to be accomplished learning and assessment proses as well as enable the interaction among students and student with instructor. Result also indicate, majority of the students have positive opinion towards e-learning nevertheless they prefer e-learning to be embedded in their education process (hybrid learning) as they are still prefer to have some level of face-to-face learning. However, this result cannot be used to generalize the opinion of all university's' student as diploma student tend to feel more comfortable to have face-to-face interaction with lecturer because they are in the transition period from school to university.
\end{abstract}

Keywords: e-learning, Technology Acceptance Model (TAM), perceived usefulness, perceived ease of use

\section{INTRODUCTION}

Education is a backbone of a country as its help to build a good society and the nation. Attending the physical schools, colleges and universities and having physical interaction with teacher or instructor is our notion of what education process should be. However, information technology becomes a new normal in our life especially in the education sector. It has changed the way of teaching and learning conducted in the sector. Traditionally, the conventional classrooms are needed for education process. But now, teaching and learning can be done with the help of technology and it is called e-learning. According to Clark and Mayer (2016), e-learning can be defined as the instruction that is intended to support learning and is delivered through digital devices. Generally, e-learning courses are using words in the form of spoken, text or pictures such as animation or video and it is designed for individual self-study. The term e-learning actually has been introduced in education widely since the mid of 1990s (Mamattah, 2016). Since then, many prestigious universities accept and offer this kind of learning such as University of North Texas (start in 1995) and University of Stanford (start in 2005).

Recently, the world was hit by Coronavirus (COVID-19) pandemic and it definitely includes Malaysia too. As a precautionary measure to control the spread of the virus, the government of Malaysia has agreed to prohibit any face-to-face teaching processes that involve students to gather around in a large group. 
Because of this precaution step, all schools, colleges, universities and institutions are temporarily closed. This has caused all teachers and lecturers need to find an alternative ways to complete the syllabus and the planned assessments without required students to gather around physically. Therefore, e-learning become viable solution or the platform in facing this pandemic. As a result, education paradigm has changed which e-learning becomes a center of attention. Thus, this study will delve into the students' perception about e-learning and their intention to use it. This study will use the theory of Technology Acceptance Model (TAM) that introduced by Fred Davis in year 1986.

According to Lai (2017), TAM is the model that specifically designed to predict the users' acceptance of technologies. In the basic TAM, there are two specific beliefs that have been tested. There are Perceived Usefulness (PU) and Perceived Ease of Use (PEU). PU and PEU have significant effect on attitude towards using technology (Maslim, 21-24 May 2007). Perceived Usefulness can be defined as the level of students' belief that by using e-learning, it will enhance their learning and Perceived Ease of Use can be defined as the degree of students expects e-learning is easy to use without the much effort (Mamattah, 2016 \& Lai, 2017). PU can influences students' intention to embrace applications of e-learning (Maslim, 212-24 May 2007; Masrom, 2007). A study conducted on 102 undergraduate students of management information system found positive finding between PU with students' engagement with internet-learning based system (ILS) or e-learning (Saade \& Bahli, 2005). A study by Liu, Ling and Peng (2005) also discovered positive finding between PU and student intention to use streaming based e-learning. Accordingly, PU is greater among learner who have higher self-efficacy (Fathema, Shannon, \& Ross, 2015). Meanwhile, strong influence of peers to adopt collaborative technology as an alternative in learning is one of the nature of PEU (Cheung \& Vogel, 2013). The system quality (SQ) provides significant positive effect on PEU. The quality issues such as functions, contents, navigation speed and interaction capability has resulted significant effect on learner positive attitude. Also, there is positive effect of PEU on PU because student believes the e-learning is useful when it is easy to use (Saade \& Bahli, 2005). However there are no significant differences of PU and PEU on gender differences which showed in data collection of three academic periods from a number of university centers (Melendez, Obra, \& Moreno, 2013).

A program and course are structured to enhance positive interaction between student, teacher and peers; however some problems do occur during online learning (Dabbagh, Fake, \& Zhang, 2019). Student satisfaction affected by instructor's interaction within online or face to face sessions (Conklina, Oyarzun, \& Barreto, 2017). According to Lowe \& Mestel (2016), online tutorial provide convenience platform to the student yet face to face session is better to practice. Students also need additional arrangement and materials in order to facilitate them to understand thus score subjects (Said \& Syarif, 2016). A study conducted by Conklina et al. (2017) observed the environment and interaction between student and instructor were rated low during online learning. Lowe \& Mestel (2016) also reported interaction between student and teacher are low for online tutorial learning. The interaction among student also becomes less productive due to technological barriers Conklina et al. (2017). As a result, students would rather choose blended learning environment although they prefer to have flexibility to learn and study that meets their needs. However, Horzum (2015) found positive result regarding interaction and social presence during online learning. This study also stated student is dissatisfied with current course structure as they think it's too heavy and reduce their interactions and social presence. Hence to increase satisfaction and students' intention to use e-learning, current course structure need to be reduced.

\section{QUESTIONNAIRE AND DATA ANALYSIS}

This study was conducted among diploma student at Universiti Teknologi MARA, Perak Branch (Tapah Campus). In order to achieve research objective of this study, a set of questionnaire is used to collect data. This questionnaire was distributed to 290 students, of these 212 were returned representing $73 \%$ of 
response rate. The respondents were selected randomly from three (3) faculties available in this campus, which are Faculty of Applied Science, Faculty of Accountancy and Faculty of Science Computer and Mathematic. Out of 212 respondents, 37\% are students from Faculty of Science Computer and Mathematic, follow by 33\% are accountancy's students and 30\% are Faculty of Applied Science.

The questionnaire was divided into five (5) parts. The first part is to collect demographic information which to understand the respondents' background information, follow by perceived usefulness of elearning, perceived ease of use of e-learning, attitude towards using e-learning and intention to use elearning in future. The questions are replicated from study by Mamattah (2016) that developed the questionnaire based on Technology Acceptance Model (TAM). Data collected from this questionnaire were entered in SPSS for purpose of data analysis and interpretation.

\section{FINDINGS AND DISCUSSION}

\section{Demographic Results}

This study comprised of $33.5 \%$ male respondents and $66.5 \%$ female respondents. Out of 212 respondents, there are 141 female and 71 male students. Respondents are reasonably distributed from different faculties which are from Faculty of Computer and Mathematical Sciences (FSKM), Faculty of Accountancy (FP) and Faculty of Applied Sciences (FSG). Thus, the data presented is representative of all students of the campus. Besides that, $90.1 \%$ of the respondents possess a personal computer while only $9.9 \%$ of them do not. Furthermore, only $15.6 \%$ of the respondents have been using the computers for less than 1 year. The other respondents have been using computer more than 1 year which is $44.3 \%$ have been using computer for between 1 to 5 years, $28.3 \%$ have using computer for between 6 to 10 years and $11.8 \%$ have been using it for more than 10 years. From the statistics, it can be seen that most of the students have more than enough experience using a computer.

\section{Perceived Usefulness of E-Learning}

In order to understand the respondents' view on e-learning, some common features were used in this study. The respondents were asked to choose from the various definitions, forms and types of e-learning that was selected. As a result, it shows that $52.8 \%$ of the respondents understand e-learning as online learning. Accordingly, this result is in line with Mamattah (2016) as 50\% of the respondents understand e-learning as online learning meanwhile $31.6 \%$ consider e-learning as learning in all forms such as learning at own pace, online learning, watching pre-recorded videos and live streaming lectures. This group of respondents believes that e-learning is not limited only to one features but also allowed the synchronous and asynchronous learning. It can further be seen in Table 1 that $7.5 \%$ of the respondents think that e-learning as learning at own pace. On the other hand, 3.8\% of them consider e-learning as watching pre-recorded videos provided by the educators. Besides, only $2.4 \%$ of the respondent has no idea about e-learning and $1.9 \%$ that think e-learning is a teaching and learning process where people having live lectures via internet.

Table 1: Understanding of E-learning by Gender

\begin{tabular}{|c|c|c|c|c|c|c|c|}
\hline & & & Descriptio & f e-learning & & & \\
\hline Gender & No idea & Own pace & $\begin{array}{l}\text { Online } \\
\text { learning }\end{array}$ & Watch video & Live lecture & All & Total \\
\hline Female & $0.0 \%$ & $5.7 \%$ & $53.9 \%$ & $2.8 \%$ & $2.1 \%$ & $35.5 \%$ & $100 \%$ \\
\hline Male & $7.0 \%$ & $11.3 \%$ & $50.8 \%$ & $5.6 \%$ & $1.4 \%$ & $23.9 \%$ & $100 \%$ \\
\hline Total & $2.4 \%$ & $7.5 \%$ & $52.8 \%$ & $3.8 \%$ & $1.9 \%$ & $31.6 \%$ & $100 \%$ \\
\hline
\end{tabular}


Pertaining to e-learning features, the feedback of respondent was recorded and illustrated in the Table 2. Result indicates that e-learning platform is suitable to cater people from different geographical areas. About $68.4 \%$ agree with this statement and only $15.1 \%$ and $16.5 \%$ choose undecided and disagree with it. It can also be seen that $67 \%$ of the respondents agree that e-learning increase the possibility of interaction among students. As the students have less interaction with the lecturers, it actually gives more space for the students to interact among them and discuss about the learning topics. Some of the respondents cannot decide on this matter and only $14.2 \%$ disagree with this feature.

Table 2: Features of E-learning

\begin{tabular}{|l|c|c|c|c|}
\hline Features of E-learning & \multicolumn{1}{c}{ Agree } & Undecided & Disagree & Total \\
\hline $\begin{array}{l}\text { Tests and assignments can be completed } \\
\text { electronically }\end{array}$ & $61.3 \%$ & $27.4 \%$ & $11.3 \%$ & $100 \%$ \\
\hline Students can learn at their own pace & 48.6 & $27.4 \%$ & $24.1 \%$ & $100 \%$ \\
\hline People can study from anywhere in the world & $68.4 \%$ & $15.1 \%$ & $16.5 \%$ & $100 \%$ \\
\hline $\begin{array}{l}\text { Interaction between instructor and students is } \\
\text { possible }\end{array}$ & $60.8 \%$ & $24.5 \%$ & $14.6 \%$ & $100 \%$ \\
\hline Interaction among students is possible & $67 \%$ & $18.9 \%$ & $14.2 \%$ & $100 \%$ \\
\hline
\end{tabular}

Besides that, $61.3 \%$ of respondents think that tests and assignments can be conducted electronically, while $27.3 \%$ were undecided and $11.3 \%$ disagree. Similar to Mamattah (2016), this study also shows that interaction between instructor and students is not supported by the respondents. The result shows that only $60.8 \%$ agree with this feature and the rest of them were undecided and disagree. This statistic is similar to study conducted by Conklina et al. (2017) that observed interaction between student and instructor were rated low during online learning. Lastly, the response concerning learning at their own pace in e-learning shows that $48.6 \%$ respondents agree and more than half respondents pick undecided and disagree. It is indicated that the respondents still find it was difficult for them to learn at their own pace as e-learning is still new learning platforms for them.

In addition to that, further exploration was conducted to know what female and male respondents think about the interaction among students who study through e-learning. The result of Chi-Square test was shown in the Table 3 below.

Table 3: Gender and View on Interaction among Students - Chi-Square Tests

\begin{tabular}{|l|r|r|r|} 
& \multicolumn{1}{c}{ Value } & \multicolumn{1}{c}{ df } & Asymptotic Significance (2-sided) \\
\hline Pearson Chi-Square & $.285^{\mathrm{a}}$ & 2 & .867 \\
\hline Likelihood Ratio & .289 & 2 & .866 \\
\hline N of Valid Cases & 212 & & \\
\hline
\end{tabular}

The result shows that there is no significant association between gender and the thought of e-learning interaction among students, $\chi^{2}(2, N=212)=0.29, p=0.867$. This finding was supported by Melendez, Obra \& Moreno (2013) that state there are no significant differences of PU and PEU on gender differences in data collection of three academic periods from a number of university centers.

This comparison of views shows that both male and female believe that there is high possibility of interaction among students where $69 \%$ of male agree on the statement, followed by $66 \%$ of female respondents. On the other hand, $16.9 \%$ of male respondents and $19.9 \%$ of female respondents were 
undecided. Besides, about $14.1 \%$ and $14.2 \%$ disagree to this possibility. This finding is contradicted with the finding in Mamattah (2016). Details of this statistics is shown in Figure 1.

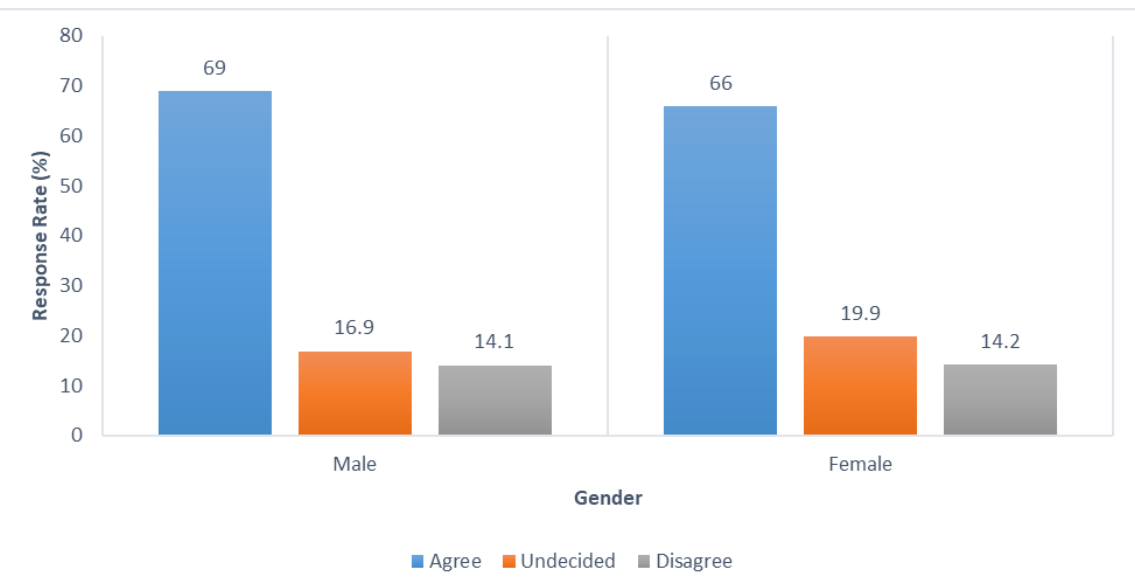

Figure 1:Comparison of the Possibility Interaction among Students by Gender

\section{Perceived Ease of Use of E-Learning}

The study found that $55.9 \%$ of the respond perceived e-learning as easy to use when they were ask on their view on the usage of e-learning. It is then followed by $23.1 \%$ students that cannot decide whether this platform can be access easily or not. Besides, $12 \%$ of the students disagree with the statement and find that e-learning is not easy to be implied in learning process. While $6.2 \%$ of the students strongly agree about the use of e-learning, there are still $2.8 \%$ of the students who strongly disagree on the elearning system. Those percentages are quite low since the person need to have good technological knowhows in order to make proper use of the e-learning tools as mentioned by Lee \& Witta (2001). The details of the result are shown in Table 4 below.

Table 4: Easy Usage of E-learning Platform

\begin{tabular}{l|l|l|l|l|l|l|}
$\begin{array}{l}\text { Easy usage of e- } \\
\text { learning platform }\end{array}$ & Strongly disagree & Disagree & Undecided & Agree & Strongly agree & Total \\
\hline User friendly & $3.3 \%$ & $16 \%$ & $26.9 \%$ & $51.9 \%$ & $1.9 \%$ & $100 \%$ \\
\hline Easy to find info & $2.4 \%$ & $8 \%$ & $19.3 \%$ & $59.9 \%$ & $10.4 \%$ & $100 \%$ \\
\hline Average & $2.8 \%$ & $12 \%$ & $23.1 \%$ & $55.9 \%$ & $6.2 \%$ & $100 \%$ \\
\hline
\end{tabular}

In addition to that, the students also find that information technology (IT) tools are very comfortable to use. $34.8 \%$ of them find that IT tools are very easy to use and $50.6 \%$ of them find that it is easy to be practiced. According to Tagoe (2012), good computer skills will help students to participate in e-learning and the comfort of using the listed tools are advantages to students. Other than that, $6.9 \%$ were undecided and $7.4 \%$ choose to put effort on trying to learn about the tools. Lastly, only $0.3 \%$ of the respondents think they cannot learn all the listed IT tools such as attaching files, chatting, downloading, and posting messages (Table 5). 


\begin{tabular}{|l|l|l|l|l|l|l|}
\hline Level of comfort using IT & Very easily & \multicolumn{1}{l|}{ Easily } & \multicolumn{1}{l|}{ Undecided } & Will try & \multicolumn{1}{l|}{ can't } & Total \\
\hline Attaching files & $30.2 \%$ & $50.9 \%$ & $7.5 \%$ & $10.8 \%$ & $0.5 \%$ & $100 \%$ \\
\hline Chatting & $38.7 \%$ & $50.5 \%$ & $5.2 \%$ & $5.2 \%$ & $0.5 \%$ & $100 \%$ \\
\hline Downloading & $36.8 \%$ & $49.1 \%$ & $6.1 \%$ & $8 \%$ & $0 \%$ & $100 \%$ \\
\hline Posting messages & $33.5 \%$ & $51.9 \%$ & $9 \%$ & $5.7 \%$ & $0 \%$ & $100 \%$ \\
\hline Average & $34.8 \%$ & $50.6 \%$ & $6.9 \%$ & $7.4 \%$ & $0.3 \%$ & $100 \%$ \\
\hline
\end{tabular}

\section{Students' Attitude towards E-Learning}

With regards to the opinion of the respondents, the result shows that only $24.1 \%$ like the idea of elearning, $42 \%$ were undecided and $33.5 \%$ disagree with the idea. However, the respondents think that elearning is not a bad platform as $52.4 \%$ of them agree that e-learning is an innovative concept and must be encouraged and $46.7 \%$ of them find that it is a fun platform to be used. Based on this results, overall respondents have positive opinion on e-learning and it will influences their behaviours towards this new platforms as mentioned by Ajzen \& Fishbein (2000). The details are shown in Table 6.

Table 6: Opinion of E-learning

\begin{tabular}{|c|c|c|c|c|}
\hline Attitude of respondents about e-learning & Agree & Disagree & Undecided & Total \\
\hline Like the idea of e-learning & $24.1 \%$ & $33.5 \%$ & $42 \%$ & $100 \%$ \\
\hline $\begin{array}{l}\text { E-learning is an innovative concept and } \\
\text { must be encouraged }\end{array}$ & $52.4 \%$ & $17.9 \%$ & $29.7 \%$ & $100 \%$ \\
\hline E-learning platform will be fun to use & $46.7 \%$ & $24.1 \%$ & $29.2 \%$ & $100 \%$ \\
\hline Average & $41.2 \%$ & $25.2 \%$ & $33.6 \%$ & $100 \%$ \\
\hline
\end{tabular}

\section{Influence of External Factors on Attitude Formation Towards E-learning}

In the concept of TAM, it was highlighted that external factors also have influence on the opinion form towards e-learning and their intention to use it (Davis et al., 1989). From the response in Table 7, 76.9\% of the respondents have receive positive encouragement from someone close and was told that it is not a difficult system to use. In addition, $63.7 \%$ of them have heard positive news report about e-learning and $59.4 \%$ heard that it is a good experience. Instead of news report, about $56.1 \%$ of the respondents indicated that they have received positive feedback from family members. On average, external factor give positive influence on attitude formation towards e-learning.

Table 7: External Influences on Attitude Formation about E-learning

\begin{tabular}{|l|l|l|l|}
\hline External factors on attitude formation & \multicolumn{1}{l}{ Positive view } & \multicolumn{1}{l|}{ Negative view } & \multicolumn{1}{l|}{ Total } \\
\hline Encouragement from someone close & $76.9 \%$ & $23.1 \%$ & $100 \%$ \\
\hline Have heard that it a good experience & $59.4 \%$ & $40.6 \%$ & $100 \%$ \\
\hline From family & $56.1 \%$ & $43.9 \%$ & $100 \%$ \\
\hline $\begin{array}{l}\text { Was told is not a difficult system to } \\
\text { use }\end{array}$ & $76.9 \%$ & $23.1 \%$ & $100 \%$ \\
\hline $\begin{array}{l}\text { Have heard positive news report about } \\
\text { e-learning }\end{array}$ & $63.7 \%$ & $36.3 \%$ & $100 \%$ \\
\hline Average & $66.6 \%$ & $33.4 \%$ & $100 \%$ \\
\hline
\end{tabular}




\section{Opinion about Employers' Acceptance}

Instead of external factors, another concern about e-learning is the acceptance of employers. In Malaysia, most people further studies in order to get a better opportunity in employment. Therefore, some was afraid that there might exist discrimination during the employment process caused by the non-face-to-face teaching and learning. Therefore, a question was included in the questionnaire to know about the respondents' opinion about this matter. The response to this question shows that $59 \%$ of the respondents think that they will suffer from this kind of discrimination. Furthermore, both male and female have the same opinion and think that they might become the victim of this issue. It can further be seen in Table 8 that only $8 \%$ of the respondents disagree and $33 \%$ were undecided.

Table 8: Fear of Employers' Discrimination by Gender

\begin{tabular}{|l|c|c|c|c|}
\hline Gender & Disagree & Undecided & Agree & Total \\
\hline Female & $7.8 \%$ & $34.8 \%$ & $57.5 \%$ & $100 \%$ \\
\hline Male & $8.5 \%$ & $29.5 \%$ & $62 \%$ & $100 \%$ \\
\hline Total & $8 \%$ & $33 \%$ & $59 \%$ & $100 \%$ \\
\hline
\end{tabular}

The Chi-square test of the relationship between gender and fear of the employers' discrimination against learner was found to be statistically not significant, $\chi^{2}(2, N=212)=0.57, p=0.751$ as shown in Table 9. Thus, it means that both male and female respondents had the same opinion on this issue.

Table 9: Fear of Employers' Discrimination by Gender - Chi-Square Test

\begin{tabular}{|l|r|r|r|}
\hline & \multicolumn{1}{|c|}{ Value } & \multicolumn{1}{c|}{ df } & Asymptotic Significance (2-sided) \\
\hline Pearson Chi-Square & $.572^{\mathrm{a}}$ & 2 & .751 \\
\hline Likelihood Ratio & .577 & 2 & .749 \\
\hline N of Valid Cases & 212 & & \\
\hline
\end{tabular}

a. 0 cells $(.0 \%)$ have expected count less than 5 . The minimum expected count is 5.69 .

\section{Cost of E-learning}

Based on the result in Figure 2, both male and female agreed that both e-learning and classroom learning have same cost. $45.3 \%$ of female respondents and $39.4 \%$ of male respondents think that the usage of IT tools will not reduce the cost of learning. In this case, researchers believe that as students has more choices of internet packages, they find that e-learning will not incurred more cost compared to the traditional method. As traditional methods cost them books, e-learning will cost them the internet access. Thus, it is similar in terms of cost. Besides that, $33.8 \%$ of male and $29.5 \%$ of female respondents think that e-learning is more expensive compared to the face-to-face learning. Contrast to that, $26.8 \%$ of male and $25.2 \%$ of female state that classroom learning is more expensive than e-learning. 


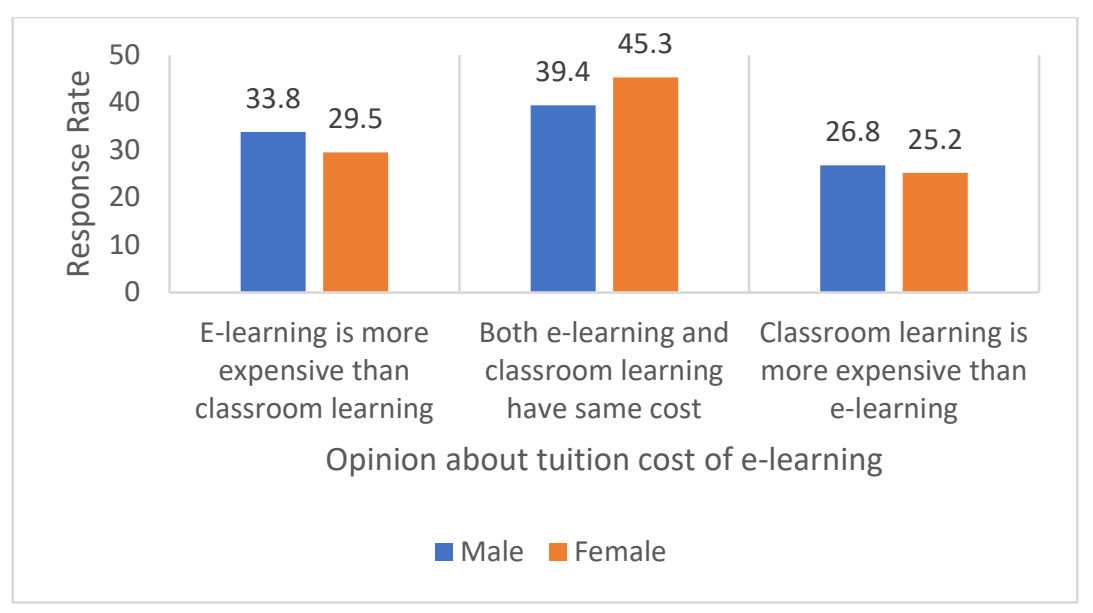

Figure 2: Opinion about Tuition Cost of E-learning by Gender

\section{Intention to Use E-Learning}

From the research data shown in Figure 3, both male and female respondents do not prefer fully online learning compared to face-to-face. Only $1.4 \%$ of male and $3.5 \%$ of female respondents that agree to adopt fully online learning system. Contrast to that, $21.1 \%$ of male and $21.3 \%$ of female respondents comfortable to face-to-face learning only. From the result, it shows that majority male and female respondents prefer hybrid learning which shows that the respondents were trying to adapt with online learning but still cannot count fully on this IT tools as the learning platform. Lowe \& Mestel (2016) in their research also find that students prefer to practice face-to-face session even though online tutorial provide convenience platform to them. Besides, it is also in line with study conducted at University of Ghana by Tagoe (2012) that shows students prefer hybrid learning as their teaching and learning platform.

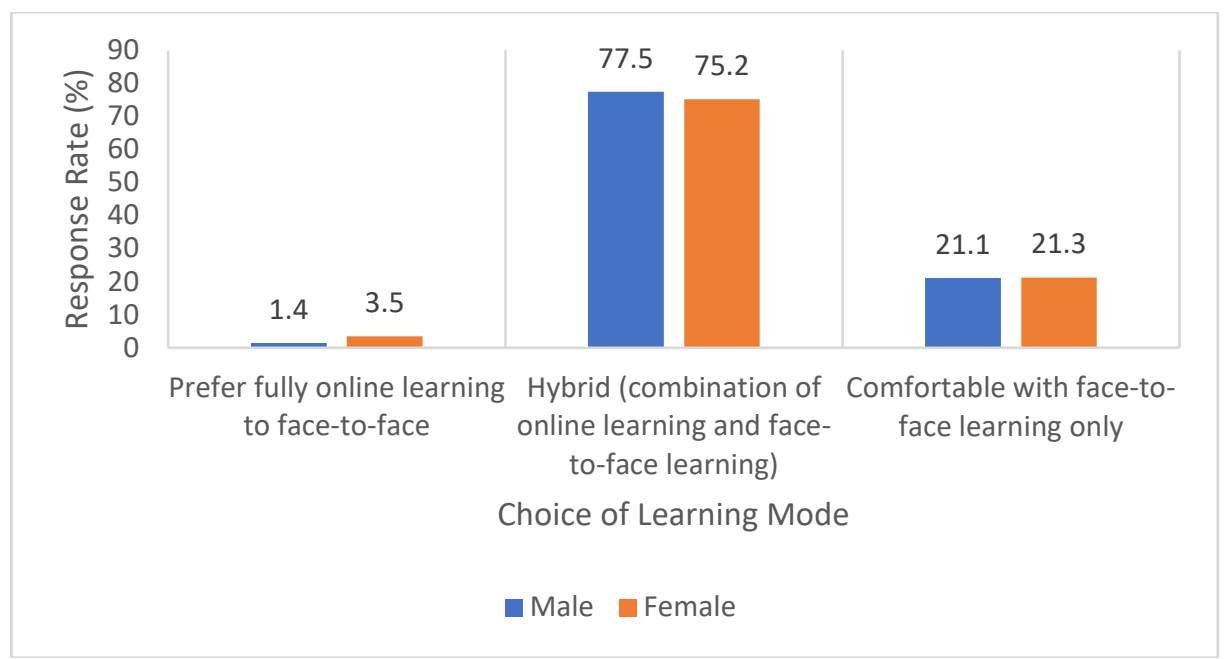

Figure 3: Choice of Learning Modes by Gender 


\section{CONCLUSION AND RECOMMENDATION}

This study was carried out to find out students' perception about e-learning. Perceptions were pursued from the students of Universiti Teknologi MARA Perak Branch (Tapah Campus) and the Technology Acceptance Model (TAM) was used as the theory for this study. Our respondents agree that e learning is useful in enhance their learning including facilitate interaction among students and between instructor and students. It has same direction on PEU as many respondents agreed that e-learning is easy to be used as their learning tools. Other than that, respondents have positive views towards e-learning. However, only $24.1 \%$ is agree when they were ask whether they like the idea of e learning. Researchers believe that this result was caused by certain factor such as fear of technology. Technology advancement in Malaysia is relatively far behind compare to other countries such as Japan and Korea. Thus, it make the students feel uncomfortable to rely only on technology especially a newly introduced. This result is contradicted with finding in Korea (where technology is more advance) which many student have intention to use elearning or m-learning as they believe it is beneficial preparation for job market (Park, Nam, \& Cha, 2012). For that reason, respondents choose hybrid learning compare to the other two choices. Overall, it shows that respondents are not rejecting e-learning. They want to use this new technology based learning but they need more time to get use to this new paradigm.

\section{REFERENCES}

Ajzen, I. \& Fishbein, M. (2000). Attitudes and the attitude-behavior relation: Reasoned and automatic processes. In W. Stroebe \& M. Hewstone (Eds.), European review of social psychology (pp. 133). John Wiley \& Sons.

Cheung, R., \& Vogel, D. (2013). Predicting User Acceptance of Collaborative Technologies: An Extension of the Technology Acceptance Model for E-Model. Computers \& Education, 63, 160175.

Clark, R.C., \& Mayer, R.E. (2016). E-learning and the science of instruction: Proven guidelines for consumers and designers of multimedia learning. John Wiley \& Sons.

Conklina, S., Oyarzun, B., \& Barreto, D. (2017). Blended Synchonous Learning Environment: Student Perspectives. Research on Education and Media, 9(1), 17-23.

Dabbagh, N., Fake, H., \& Zhang, H. (2019). Student Perspectives of Technology Use for Learning in Higher Education. Revista Iberoamericana de Education a Distancia, 22(1), 127-152.

Davis, F. D., Bagozzi, R. P. \& Warshaw, P. R. (1989). User acceptance of computer technology: A comparison of two theoretical models. Management Science, 35(8), 982-1003. http://www.jstor.org/pss/2632151

Fathema, N., Shannon, D., \& Ross, M. (2015). Expanding the Technology Acceptance Model (TAM) to Examine Faculty Use of Learning Management Systems (LMSs) in Higher Education Institutions. MERLOT Journal of Online Learning and Teaching, 11(2), 210-232.

Horzum, M. B. (2015). Interaction, structure, Social Presence, and Satisfaction in Online Learning. Eurasia Journal of Mathematics, Science \& Technology Education, 11(3), 505-512.

Lai, P. (2017). The Literature Review of Technology Adoption Models and Theories for The Novelty Technology. Joirnel of Information Systems and Technology Management, 14(1), 21-38. 
Lee, C., \& Witta, L. (2001). Online students' perceived self-efficacy: Does it change? Paper presented at the national convention of the Association for Educational Communications and Technology, Atlanta, GA.

Liu, S.-H., Liao, H.-L., \& Peng, C.-J. (2005). Applying the Technology Acceptance Model and Flow Theory to Online E-Learning Users' Acceptance Behavior. Issues in Information Systems, VI(2), 175-181.

Lowe, T., \& Mestel, B. a. (2016). Perceptions of Online Tutorials for Distance Learning in Mathematics and Computing. Research in Learning Technology. 24. Article no. 30630.

Mamattah, R. S. (2016). Students' Perceptions of E-Learning.

Maslim, M. (21-24 May 2007). Technology Acceptance Model and E-Learning. 12th International Conference on Education (pp. 1-10). Brunei: Sultan Hassanal Bolkiah Institute of Education.

Masrom, M. (2007). Technology acceptance model and e-learning. In: 12th International Conference on Education, 21-24 May 2007, Sultan Hassanal Bolkiah Institute of Education, Universiti Brunei Darussalam http://eprints.utm.my/5482/1/MaslinMasrom2006_Techn.pdf

Meléndez, A. P., Obra, A. R., \& Moreno, A. G. (2013). Perceived Playfulness, Gender Differences and Technology Acceptance Model in a blended Learning Scenario. Computers \& Education, 63, 306-317.

Park, S. Y., Nam, M. W., \& Cha, S.-B. (2012). University Students' Behavioral Intention to Use Mobile Learning: Evaluating the Technology Acceptance Model. British Journal of Education Technology, 43(4), 592-605.

Saadé, R., \& Bahli, B. (2005). The Inpact of Cognitive Absorption on Perceived Usefulness and Perceived Ease of Use in On-Line Learning: An Extension of the Technology Acceptance Model. Information \& Management, 42, 317-327.

Said, A., \& Syarif, E. (2016). The Development of Online Tutorial Program Design Using ProblemBased Learning in Open Distance Learning System. Journal of Education and Practice, 7(18), 222-229.

Tagoe, M. (2012). Students' perceptions on incorporating e-learning into teaching and learning at the University of Ghana. International Journal of Education and Development using Information and Communication Technology (IJEDICT), 2012, Vol. 8, Issue 1, pp. 91-103. 